\title{
ИЗМЕНЕНИЕ МИКРОБИОМА МЕЛКОГО СОЛОНЦА ПОД ДЕЙСТВИЕМ ДЛИТЕЛЬНОГО ВОЗДЕЛЫВАНИЯ ДОННИКА
}

\section{CHANGES IN THE MICROBIOME OF SMALL SOLONETZ UNDER \\ THE INFLUENCE OF LONG-TERM CULTIVATION OF SWEET CLOVER \\ V. Riksen \\ L. Korobova \\ T. Lomova}

Summary. The article presents the results of a five-year study of plantmicrobial interactions in small solonetz in the Barabinsk lowland of Siberia where yellow sweet clover was cultivated in the fodder crop rotation for 33 years. The phytomeliorative effect of the sweet clover was manifested in the desalting of the small solonetz and replenishment of the nitrogen fund of the soil. Under the sweet clover at the layer of $0-20$ $\mathrm{cm}$, the oligotrophy of the soil decreased by more than two times and the microbial transformation of plant residues into humus compounds became two times more active. The prokaryotic microbiome became somewhat more diverse; the number of orders and families of bacteria and archaea, as well as their genera, increased to 387 against 311 in virgin soil. The influence of the sweet clover changed the metagenome of the small solonetz at the level of phylum and classes, selecting it towards the representation of copiotrophs that play a significant role in the carbon and nitrogen cycles.

Keywords: small solonetz, phytomelioration, yellow clover, soil microorganisms, microbiome, taxonomy.
Риксен Вера Сергеевна

Аспирант, Новосибирский государственный аграрный университет; м.н.с., Сибирский федеральный научный чентр агробиотехнологий РАН Riclog@mail.ru

Коробова Лариса Николаевна

Д.б.н. профессор, Новосибирский государственный аграрный университет Ломова Татьяна Григорьевна К.с.-х.н., в.н.С., Сибирский федеральный научный иентр агробиотехнологий РАН

Аннотация. В статье приведены результаты пятилетних исследований, связанных с изучением растительно-микробных взаимодействий в солонце мелком средненатриевом Барабинской низменности Сибири, где в течение 33-х лет в кормовом севообороте возделывался донник желтый. Фитомелиоративное действие донника проявилось в рассолении мелкого солонца и пополнении азотного фонда почвы. Под донником в слое 0-20 см более чем в 2 раза снизилась олиготрофность почвы и в 2 раза активнее стала микробная трансформация растительных остатков в соединения гумуса. Микробиом прокариот несколько разнообразился, в нем увеличилось число порядков и семейств бактерий и архей, а также родов до 387 против 311 в целине. Влияние донника изменило метагеном мелкого солонца на уровне филумов и классов, отселектировав его в сторону представительства копиотрофов, играющих значительную роль в круговоротах углерода и азота.

Ключевые слова: мелкий солонец, фитомелиорация, донник желтый, микроорганизмы почвы, микробиом, таксономия.

лее 3-5 ц низкокачественного сена [1], поэтому в сельскохозяйственной практике на солонцах высевают засухо- и солеустойчивые однолетние и многолетние высокопродуктивные кормовые травы. Они способны обогащать почву органическим веществом и кальцием и постепенно ее рассолять, т.е. оказывать фитомелиоративное воздействие [7, 2].

Среди фитомелиорантов одним из лучших считается донник Melilotus Mill. На засоленных почвах он показывает устойчивую кормовую и семенную продуктивность, проявляет засухоустойчивость и зимостойкость, устойчивость к вредителям и болезням. Донник хорошо рассоляет почву и улучшает ее теплофизические свойства, поэтому рекомендован к использованию в мелиоративных севооборотах на солонцах $[6,3,10$, 20]. В Барабе донниковые шестипольные севообороты изучаются на солонцовом стационаре СибНИИКор- 
мов с 1987 года. Установлено, что фитомелиоративное воздействие донника совместно с обработкой почвы (раз за ротацию послойное фрезерование верхнего горизонта, далее рыхление) проявилось в улучшении водно-физических свойств и химических показателей плодородия мелкого и среднего солонцов [7, 13, 1]. Для микрофлоры было показано, что три ротации донникового севооборота увеличили биогенность слоя 0-20 см солонцов, особенно обилие нитрификаторов и актиномицетов [9]. К настоящему времени с момента закладки фитомелиоративных севооборотов с донником прошло 33 года.

\section{Шель $\triangle$ анной работы}

Показать, как изменилась биологическая активность мелкого солонца при длительном возделывании донника и выявить особенности таксономической структуры его микробного сообщества в сравнении с целинным солонцом.

\section{Объекты и методы исслеАования}

Исследования провели в Барабинской лесостепи на стационаре СФНЦА РАН (СибНИИКормов) в Чановском районе Новосибирской области. Географические координаты стационара: 55,389 с.ш., 78,927 в.д.

Объект исследования - солонец мелкий высокостолбчатый средненатриевый содово-сульфатного типа засоления тяжелого гранулометрического состава. Содержание гумуса в горизонте А при закладке опыта в 1987 г. в почве составляло 5,8\% от массы солонца, $\mathrm{pH}_{K C l}=7,7-8$ [12].

Изучались варианты: 1) целина, 2) донник второго года жизни в шестипольном севообороте: донник с покровной культурой суданской травой - донник второго года жизни - овес на зерносенаж - донник с суданской травой - донник - овес на зерносенаж. Высевался донник желтый сорта Альшеевский.

Биологическую активность почвы исследовали в 2008, 2009, 2016, 2018 и 2020 гг., таксономическую структуру микробиома - в 2020 г. Почву отбирали в первых числах августа из слоя 0-20 см (в целине 0-15 см) на нечетных делянках размером 200 м² в 6-ти повторениях буром. Биологическую активность почвы характеризовали, используя коэффициенты минерализации (КАА/МПА), олиготрофности (ГА/МПА) и микробиологической трансформации растительных остатков в органическое вещество почвы. Коэффициент вычислен по формуле, предложенной В.Д. Мухой (1980): Пм $=(\mathrm{MПA+KАA})$ x (МПА/ КАА $)$. Для этого классическими методами микробиологии анализировали почву сме- шанного образца каждого варианта, выделяя бактерии, усваивающие органический и минеральный азот и олигонитрофилов. Повторность микробиологических посевов на твердые питательные среды - трехкратная [11].

Таксономическую принадлежность микроорганизмов выявляли метагеномным анализом последовательностей генов $16 \mathrm{~S}$ рPHК. Анализ выполнен на базе ИХБФМ СО РАН (г. Новосибирск) в ЦКП «Геномика». ДНК бактерий и архей выделяли из 0,5 г почвы в 4 повторениях для каждого варианта. ДНК экстрагировалась при помощи наборов Spin Kit for Soil (Mo-Bio, Калифорния, (ША) и QIAAMP DNA STOOL MINI KIT по протоколам производителей. Для обработки образцов в процессе Qiagen применялся гомогенизатор TissueLyser II (45 c, 5000 об/мин.). Качество извлеченной ДНК оценивалось электрофорезом в 1\% агарозном геле.

Полученный препарат ДНК использовался как матрица в ПЦР с применением праймеров к вариабельному участку V3-V4 генов $16 \mathrm{~S}$ pPHK F343 (5'-CTCCTACGGRRSGCAGCAG-3') и R806 (5'-GGACTACNVGGGTWTCTAAT-3') в сочетании с адаптерными последовательностями Illumina и Barcode на праймерах. ПЦР-амплификация проводилась в объеме 50 мкл реакционных смесей. Пробы подготавливались и секвенировались на приборе MiSeq (Illumina, США) в соответствии с рекомендациями производителя.

Секвенированные последовательности анализировались в программе USEARCH. В ходе анализа выполнялась проверка качества секвенирования, фильтрация последовательностей нуклеотидов по длине и качеству, отбрасывание синглтонов, химер, объединение последовательностей в операционные таксономические единицы ОТЕ (виды) на основе порога сходства генов, равном 97\%. Последовательности ОТЕ были отнесены к таксонам с помощью SINTAX [18]. Таксономическую структуру бактерий и архей отразили через процентное представительство отдельных таксонов в общем числе нуклеотидных последовательностей.

Общее содержание солей в почве определили по удельной электропроводности почвенной пасты - УЭП, используя для анализа разведение почвы 1:5 и кондуктометр-иономер [4].

\section{Результаты и обсужьение}

Фитомелиорацию за рубежом считают недорогим, но малорентабельным методом в изменении свойств почвы в сравнении с использованием химических мелиорантов [25]. При анализе солонцов Барабы, транс- 
Таблица 1. Показатели биологической активности солонца мелкого и изменение его засоленности при длительном возделывании севооборота с донником (среднее за 2008-2009, 2016, 2018, 2020 гг.)

\begin{tabular}{|c|c|c|c|c|}
\hline \multirow{2}{*}{ Вариант } & \multicolumn{2}{|l|}{ Целина } & \multicolumn{2}{|c|}{$\begin{array}{l}\text { Фитомелиорированный } \\
\text { солонец }\end{array}$} \\
\hline & среднее & медиана & среднее & медиана \\
\hline Коэффициент минерализации & 11,1 & 7,3 & 11,7 & 11,7 \\
\hline 2. Коэффициент олиготрофности & 8,2 & 5,4 & $3,4^{*}$ & 1,0 \\
\hline $\begin{array}{l}\text { 3. Коэффициент трансформации растительных остатков } \\
\text { в органическое вещество почвы }\end{array}$ & 101,0 & 71,5 & $223,7^{*}$ & 181,1 \\
\hline $\begin{array}{l}\text { 4.Удельная электропроводность почвенного раствора, мкСм/см, } \\
\text { HCP }_{05}=154,8 \text { (2018 г.) }\end{array}$ & 1050,5 & & $98,1^{*}$ & \\
\hline
\end{tabular}

Примечание. *Различия с целиной достоверны на 95\% уровне значимости

формированных химическим мелиорантом - фосфогипсом, биологическая активность почвы показала себя как чувствительный индикатор постмелиоративных изменений [24]. В данных исследованиях тоже выявились существенные отличия в изученных биологических показателях солонца мелкого.

Прежде всего, при длительном возделывании кормового севооборота с донником произошло значительное рассоление верхнего горизонта солонцовой почвы (табл. 1). В исходном целинном солонце содержание обменного $\mathrm{Na}$ в слое 10-20 см составляло 25,5\% от суммы поглощенных оснований [8]. По значениям удельной электропроводности (УЭП) такой солонец относился к среднезасоленным. Фитомелиорированная солонцовая почва, благодаря доннику, перешла в разряд незасоленных, т.к. за 31 год действия агробиологического метода количество солей в ней в слое 0-20 см снизилось в 10,7 раза.

С содержанием солей в почве было тесно связано обилие олигонитрофильных микроорганизмов. Оно положительно коррелировало с УЭП с $r=0,944 \pm 0,06$. Олигонитрофилы обычно многочисленны в средах обитания с низкими концентрациями азота. В целинном солонце соотношение между этой группы и численностью копиотрофных бактерий на МПА (коэффициент олиготрофности) превосходило трансформированную донниковым севооборотом почву в 2,4 раза, что свидетельствует о повышенном содержании азота под фитомелиорантом.

Также под севооборотом с донником усилилась микробиологическая трансформация растительных остатков в органическое вещество почвы (коэффициент Пм в табл. 1), приводящее к развитию дернового процесса. Скорость микробиологического гумусонакопления в среднем за годы исследований в трансформированном солонце превысила целинную почву в 2,2 раза.
По истечении 33-летнего срока фитомелиорации наметились сдвиги в биологическом разнообразии почвенных бактерий и архей. Биорегулирование солонцовой почвы севооборотом с донником проявилось в возрастании в ней геномных последовательностей и видового разнообразия. Всего здесь было выявлено 49099 микробных OTUS, в то время как в изученных образцах целинного солонца 47861. Разнообразие микроорганизмов в агроизмененном солонце представляли 120 порядков (в целине их было 113), 213 семейств (против 191 в целине) и 387 родов бактерий и архей (в целине 331).

Состав сообщества прокариот мелкого солонца Барабы в основном был сформирован доменом Bacteria с доминированием представителей 4 групп: Acidobacteria, Proteobacteria, Actinobacteria, Verrucomicrobia. В целинном солонце самым распространенным филумом являлся Actinobacteria, на долю которого приходилось 30,3\% видов сообщества. На 2 месте находились ацидобактерии с долевым присутствием 25,1\%, 3 место занимали протеобактерии - 13,4\% сообщества. Согласно таксономической идентификации среди ацидобактерий наиболее многочисленными были Gp4 и unc_Acidobacteria, среди протеобактерий класс Alphaproteobacteria. Доминировал здесь род Sphingomonas с содержанием, в 1,5 раза превышающим фитомелиорируемый мелкий солонец, что, возможно, связано с низкой концентрацией питательных веществ в целинной почве $[17,21]$.

В микробиоме трансформированного фитомелиорацией солонца доля актиномицетов сократилась в 2,2 раза. До 32,7\% возросла доля ацидобактерий (прежде всего групп Gp1, Gp6 и неатрибутируемых представителей Acidobacteria) и до 16,5\% увеличилась численность почвенных протеобактерий, в основном из класса $\beta$-Proteobacteria. Среди них много копиотрофов, адаптированных к большому содержанию в почве 
углерода и играющих значительную роль в круговороте азота и связывании биогеохимии углерода и железа [19].

Многочисленными в солонце с донниковой растительностью стали виды из типа Verrucomicrobia - еще одной группы, сильно реагирующей на увеличение органического вещества почвы [16]. Их процентное содержание в сравнении с целинным мелким солонцом возросло в 2 раза и составило в трансформированном солонце $14,7 \%$ против 7,2\% в целине.

Представительство архей в Барабе, в сравнении с прикаспийским мелким солонцом (микробиом которого описан Т.И. Черновым в [15] и где в слое 0-20 см обнаружено до $12 \%$ архей из филума таумархеот) незначительно. В целине их 0,03\% от общего числа OTUS, под донником 0,04\%. Причина этого, по-видимому, связана с генезисом солонцов Барабы. Почвоведы Сибири Н.В. Семендяева и Н.И. Добротворская считают, что исходно на месте солонцов Барабинской низменности были луговые и лугово-черноземные почвы, которые постепенно минерализовались солесодержащими грунтовыми водами [14].

В целом, сравнение таксономической структуры микробиомов целины и измененной фитомелиорацией почвы указывает на то, что биоразнообразие поч- венных прокариот в мелком солонце связано с растительно-микробными взаимодействиями достаточно сильно.

\section{Зак^ючение}

Длительное, в течение трех десятилетий, фитомелиоративное действие на мелкий солонец кормового севооборота с донником проявляется в его рассолении и пополнении азотного фонда почвы. Под донником в верхнем горизонте почвы более чем в 2 раза снижается олиготрофность и в 2 раза лучше за счет микробиологической трансформации растительных остатков в гумусовые соединения почвы обеспечивается дерновый процесс.

Под действием длительного возделывания донникового севооборота почвенный микробиом прокариот ставится более разнообразным: в нем увеличивается число порядков, семейств и родов бактерий и архей. Влияние донника изменяет метагеном мелкого солонца на уровне филумов и классов, селектируя его в сторону представительства копиотрофов, играющих значительную роль в круговоротах углерода и азота.

Исследование выполнено при финансовой поддержке РФФИ в рамках научного проекта № 20-3490096.

\section{ЛИТЕРАТУРА}

1. Елизаров Н.В., Ломова Т.Г., Устинов М.Т., Попов В.В. Действие агробиологической мелиорации на солевой профиль солонцов Восточной Барабы // Вестник НГАУ. 2019. № 1. С. 18-25. D0I: 10.26898/0370-8799-2018-6-2

2. Елизаров Н.В., Попов В.В. Влияние агробиологической мелиорации на почвенный поглощающий комплекс солонцов Барабинской низменности // Сибирский вестник сельскохозяйственной науки. 2018. Т. 48. № 6. С. 13-20.

3. Жумадилова Ж.Ш., Мухамбетов, Б., Абдиева К.М., Шорабаев Е.Ж., Саданов А.К. Влияние донника на солевой режим и органо-минеральный состав почвы рисового севооборота в условиях Приаралья //Успехи современного естествознания. 2014. № . 12-5. С. 546-549.

4. Зайдельман Ф.Р. Мелиорация почв. М.: Изд-во МГУ, 2003. 448 с.

5. Звягинцев Д.Г. Почва и микроорганизмы. М.: Изд-во Моск. ун-та, 1987. 256 с.

6. Кирпичев И.В., Наумов С.Ю. Однолетний и двулетний донник. - Луганск: Изд-во «Укрроспроммаш», 2002.100 с.

7. Константинов М.Д. Агробиологический метод мелиорации солонцов Южного Урала и Западной Сибири / Рос. акад. с.-х. наук. Сиб. отд-ние. Сиб. науч.-исслед. ин-т кормов. Новосибирск, 2000. 359 с.

8. Костантинов М.Д., Кухарь М.А. Улучшение свойств черноземно-луговых мелких солонцов в фитомелиоративных луговых севооборотах Западной Сибири //Доклады Российской академии сельскохозяйственных наук. 2006. № . 6. С. 31-34.

9. Ломова Т.Г., Коробова Л.Н. Фитомелиоративное окультуривание солонцов Барабы и его влияние на биологическую активность почвы // Сиб. вестник с.-х. науки. 2015. № 1. С. 12-18.

10. Макарычев С.В. Влияние фитомелиорации на улучшение теплофизического режима солонцовых почв сухостепной зоны Алтайского края //Вестник Алтайского государственного аграрного университета. 2016. № . 9 (143). С. 34-38.

11. Муха В.Д. 0 показателях, отражающих интенсивность и направленность почвенных процессов: Сб. науч. тр. Харьковского СХИ. Харьков, 1980. Т. 273. C. 13-16.

12. Реестр длительных стационарных полевых опытов государственных научных учреждений Сибирского отделения Россельхозакадемии / Сост.: Л.Ф. Ашарина, А.И. Ермохина, Т.А. Галактионова. Новосибирск, 2009. 285 с.

13. Семендяева Н.В., Ломова Т.Г., Утенков Г.Л. Научное обеспечение сельскохозяйственного освоения солонцовых почв юга западной Сибири за период с 1969 по 2014 г.//Вестник НГАУ. 2016. № . 1. С. 7-22. 
14. Семендяева Н.В., Добротворская Н.И. Теоретические и практические химической мелиорации солонцов Западной Сибири: монография. Новосибирск, 2005. $156 \mathrm{c}$.

15. Чернов Т.И. Метагеномный анализ прокариотных сообществ профилей почв Европейской части России: автореферат дис. ... канд. биол. наук. М. 2016. 23 c.

16. Bergmann G.T., Bates S.T., Eilers K.G., Lauber C.L., Caporaso J.G., Walters W.A., Knight R., Fierer N. The under-recognized dominance of Verrucomicrobia in soil bacterial communities // Soil Biology, Biochemistry, 2011. Vol. 43. № 7. P. 1450-1455. doi: 10.1016/ j.soilbio.2011.03.012.

17. Chaves M.G., Silva G.G.Z., Rossetto R., Edwards R.A., Tsai S.M., Navarrete A.A. Acidobacteria Subgroups and Their Metabolic Potential for Carbon Degradation in Sugarcane Soil Amended With Vinasse and Nitrogen Fertilizers. // Front. Microbiol. 2019. № 10 P. 1680. C. 1-16 doi: 10.3389/ fmicb. 2019.01680.

18. Edgar R.C. SINTAX, a Simple Non-Bayesian Taxonomy Classifier for 165 and ITS Sequences // bioRxiv preprint. Version posted September 9 , 2016. doi: doi. org/10.1101/074161

19. Krishna M., Gupta S., Delgado-Baquerizo M., Morriën E., Garkoti S.C. et al. Successional trajectory of bacterial communities in soil are shaped by plant-driven changes during secondary succession //Scientific reports. 2020. № 10. P. 1-10.

20. Muntyan A.N., Belova V.S., Chizhevskaya E.P., Rumyantseva M.L., Simarov B.V., Andronov E.E. Molecular analysis of the genetic diversity of populations of sweet clover (Melilotus dentatus Pers.) // Sel'skokhozyaistvennaya Biologiya [Agricultural Biology]. 2012. № 6. P. 92-99.

21. Nishiyama M., Senoo K., Wada H., Matsumoto S. Identification of soil micro-habitats for growth, death and survival of a bacterium, $g$-1,2,3,4,5,6hexachlorocyclohexane-assimilating Sphingomonas paucimobilis, by fractionation of soil // FEMS Microbiol. Ecol. 1992. Vol. 101. P. 145-150.

22. Prosser J.I. Dispersing misconceptions and identifying opportunities for the use of'omics' in soil microbial ecology //Nature Reviews Microbiology. 2015 . Vol.13. № 7. P. 439-446.

23. Ryan M.H., Graham J.H. Little evidence that farmers should consider abundance or diversity of arbuscular mycorrhizal fungi when managing crops // New Phytol. 2018. Vol. 220. P. 1092-1107.

24. Semendyaeva N.V., Korobova L.N., Elizarov N.V. Changes in the Properties and Biological Activity of Crusty Solonetzes in the Baraba Lowland under the LongTerm Impact of Gypsum// Eurasian Soil Science. 2014. № 11. P. 1116-1122.

25. Trivedi R. Ecology of saline soil microorganisms //Bioremediation of Salt Affected Soils: An Indian Perspective. — Springer, Cham, 2017.— C. 157-171.

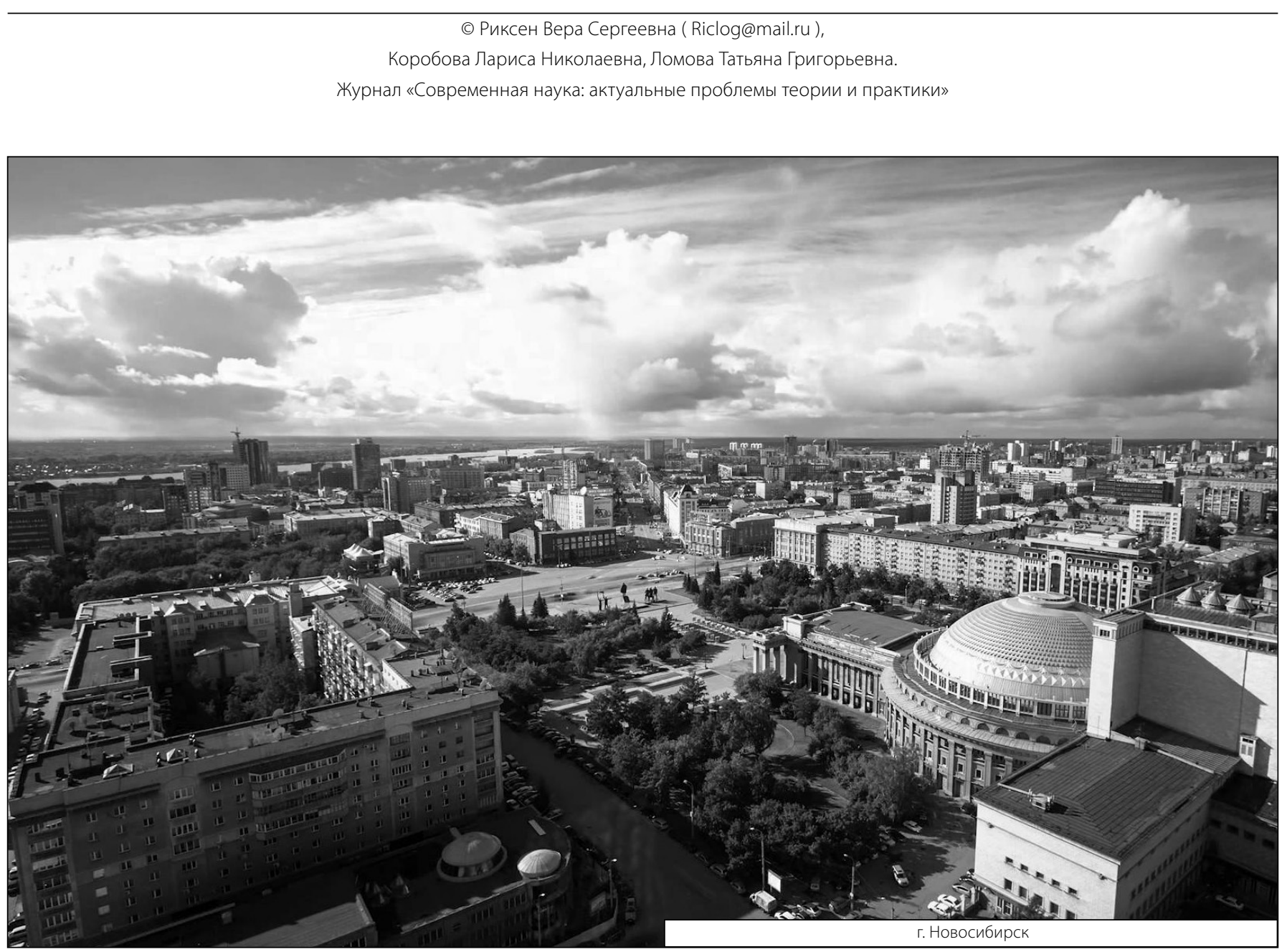

